\title{
Distribution and morphometry of shallow lakes in a temperate zone (Buenos Aires Province, Argentina)
}

\author{
Vanesa Y. Bohn ${ }^{* 1,2}$, Gerardo M. E. Perillo ${ }^{1,3}$ and María C. Piccolo ${ }^{1,2}$ \\ ${ }^{1}$ CONICET-Instituto Argentino de Oceanografía (IADO). CC 804 B8000FWB Bahía Blanca. Argentina. \\ ${ }^{2}$ Departamento de Geografía y Turismo, Universidad Nacional del Sur (UNS) 12 de octubre y San Juan. $4^{\circ}$ piso. \\ 8000 Bahía Blanca, Argentina. \\ ${ }^{3}$ Departamento de Geología, UNS. San Juan 670. $1^{\circ}$ piso. 8000 Bahía Blanca, Argentina. \\ * Corresponding author: vbohn@ criba.edu.ar
}

Received: 21/8/10

Accepted: 14/3/11

\begin{abstract}
Distribution and morphometry of shallow lakes in a temperate zone (Buenos Aires Province, Argentina)

We have developed a database of water bodies to characterise and assess the distribution and morphometry of Pampean shallow lakes and reservoirs in a temperate zone (Buenos Aires Province, Argentina). In the study area, there are over 2000 shallow lakes with a mean area $<1 \mathrm{~km}^{2}$.

The spatial variation in the shallow lakes studied is related to alternating periods of different hydrological conditions and the flatness of the Pampean landscape. The aim of this research is both to establish a classification system for the shallow lakes in the studied area and to evaluate the influence of rainfall regime on their morphometry. This classification system will provide a typological reference against which the ecological state of waters can be assessed.

The spatial distribution, morphometry and changes in the size of the shallow lakes in southern Buenos Aires were studied during two periods: a normal (a year with average rainfall) and a wet year. A Geographic Information System (GIS) as well as satellite imaging and Digital Elevation Model (DEM) data were used to calculate the morphometry of the shallow lakes and observe changes over time.

Based on climatic criteria, geomorphology, soils and hydrology, four groups of lakes were identified: 1) plain and plateau lakes (constituting the highest proportion of circular shallow lakes), 2) artificial lakes (a category constituted solely of the only water reservoir in the studied area), 3) coastal plain lakes characterised by a Coastal Line Development (CLD) $<2$ and 4) coastal plain lakes characterised by a CLD $>2$. In the last two cases, geomorphology determines the morphometry and location of these shallow lakes. The development of numerous water bodies with areas $<1 \mathrm{~km}^{2}$ caused a significant increase in the number of water bodies during the wet year. The areal coverage and density of lakes is lowest in the western plateau zones, low near the hills, moderate in the centre of the study area and high in the eastern plains.
\end{abstract}

Key words: Shallow lake morphometry, spatial distribution, precipitation regime, southern Buenos Aires Province.

\section{RESUMEN}

\section{Distribución y morfometría de lagos someros en una zona templada (provincia de Buenos Aires, Argentina)}

Se desarrolló una base de datos de cuerpos de agua para caracterizar la distribución y la morfometría de lagos someros y reservorios pampeanos en una zona templada (provincia de Buenos Aires, Argentina). En el área de estudio existen más de 2000 lagos someros con un área media menor a $1 \mathrm{~km}^{2}$.

La variación espacial se relaciona con la alternancia de períodos de condiciones hidrológicas distintas y con el relieve plano característico del paisaje pampeano. El objetivo de esta investigación es realizar una clasificación de los lagos del área de estudio y evaluar la influencia de un parámetro climático (precipitación) sobre su morfometría. Se espera que esta clasificación pueda contribuir al asesoramiento del estado ecológico de las aguas.

La distribución espacial, los parámetros morfométricos y cambios de extensión de los lagos someros en el sur de la provincia de Buenos Aires fueron estudiados durante dos períodos: un año normal y un año húmedo. Se aplicó un Sistema de Información Geográfica (SIG), datos satelitales y un Modelo de Elevación Digital (MED) para el cálculo de la morfometría de los lagos someros y sus cambios a lo largo del tiempo. 
Se identificaron 4 grupos de lagos sobre la base de criterios climáticos, geomorfológicos, edáficos e hidrológicos: 1) Lagos de planicie (la mayor proporción de lagos someros circulares), 2) Lagos artificiales (constituido por el único lago artificial del área de estudio), 3) Lagos de planicie costera (Desarrollo de Línea de Costa $(D L C)<2)$ y 4) Lagos de planicie costera (DLC>2). En los últimos dos casos, la morfometría y la localización de los lagos fue influenciada por la geomorfología. El desarrollo de numerosos cuerpos de agua cuya área media es menor a $1 \mathrm{~km}^{2}$ causó un incremento en el número de cuerpos de agua durante el año húmedo. El área cubierta por agua y la densidad de los lagos fue más baja en la zona de mesetas (situada al oeste del área de estudio), baja en la zona serrana, moderada en el centro del área de estudio y alta en las planicies del sector este del área de estudio.

Palabras clave: Morfometría de lagos someros, distribución espacial, régimen de precipitación, sur de la provincia de Buenos Aires.

\section{INTRODUCTION}

Variations in distribution and morphometry strongly influence the productivity and eutrophic state of a lake (Wetzel, 2001). This variability, a consequence of anthropogenic action and, in temperate zones, seasonal climatic events, has been thoroughly investigated (Quirós et al., 2002; Geraldes \& Boavida, 2005). The ecological importance of morphometry was demonstrated by Tavernini et al. (2003) in their study on the influence of water body morphometry on the distribution of some zooplankton species.

Because the morphometry and distribution of shallow lakes influence numerous aspects of their functioning, investigations of these subjects are diverse (Vega et al., 2005; Rooney \& Kalff, 2000; Cheruvelil \& Soranno, 2008). Ambrosetti \& Barbanti (2002) established a distinction between deep and shallow lakes by carefully examining the mean energy variations in the water mass of 31 Italian lakes in relation to their morphometric and geographic characteristics. They found a significant correlation between the heat content and morphometric parameters of these of lakes.

Kolada et al. (2005) used cluster analysis to determine the relative importance of several abiotic lake parameters in the composition of a lake typology. They categorised 749 Polish lakes by morphometry, with the aim of characterising the relationships between the abiotic and biotic classes and determining whether variations in abiotic conditions correspond to variability in biotic assemblages. Morphometric factors were considered because the functioning of shallow, non-stratified lakes is different from that of deep water bodies.

Temporal changes in the distribution and morphometry of shallow lakes over time are related to land use in areas where agriculture is the most significant economic activity, making lake distribution relevant to the planning of economic activities in such regions. In a study estimating the number, density, and area of small water bodies across the United States; Smith et al. (2002) concluded that small water bodies are numerous across the United States and that the highest concentration of artificial lakes is in agricultural regions. Their analyses also demonstrated the role of transition from positive to negative water balance in shaping the distribution of water bodies.

Remote sensing techniques are frequently used to detect changes in lakes and flooded surfaces, both continuously and at different time points. For instance, an efficient method for mapping flood extent using Landsat 7 Thematic Mapper (TM) imagery and Digital Elevation Model (DEM) data was developed by Wang et al. (2002) in response to the extensive flooding that occurred in eastern North Carolina after Hurricane Floyd. This method was based on the reflectance of water versus non-water targets on a pair of Landsat 7 TM images taken before and during the flood event, and Digital Elevation Model (DEM) data were used to model inundation. The method was found to be reliable and readily applicable to other coastal floodplains, especially because the data used are relatively easy and costefficient to obtain and analyse. 


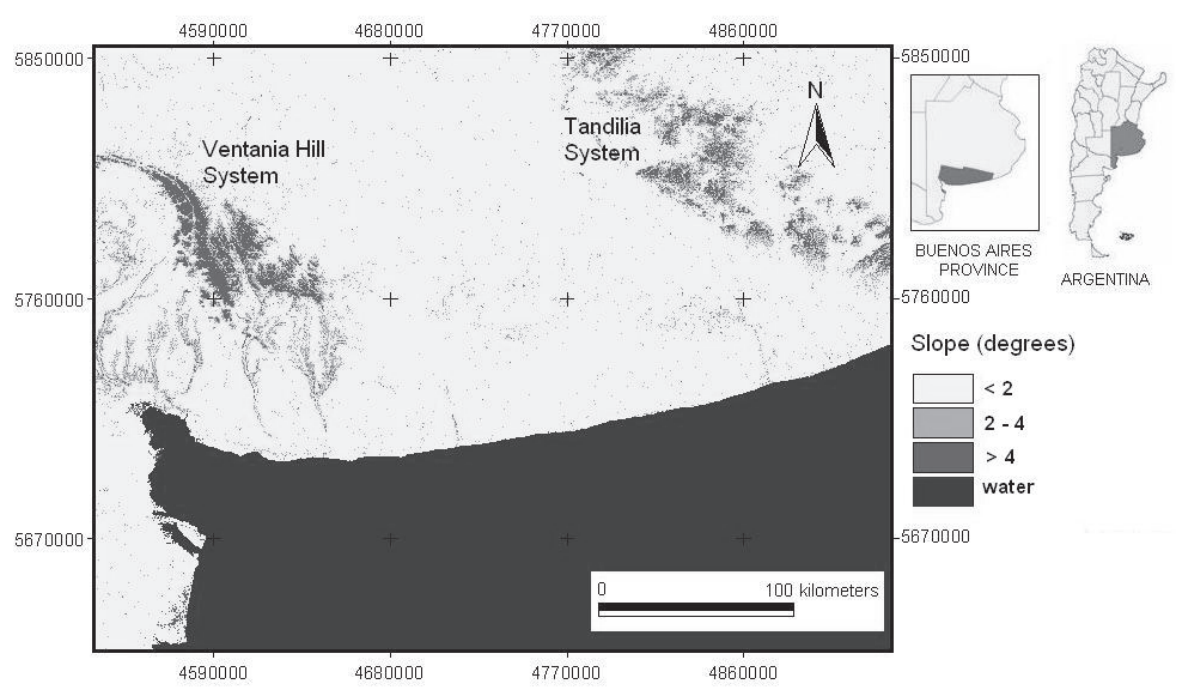

Figure 1. Location and topographic slope of the study area in the south of Buenos Aires Province, Argentina. Localización $y$ pendiente topográfica del área de estudio en el sur de la provincia de Buenos Aires (Argentina).

In a study conducted on a regional scale, seven water bodies in Buenos Aires, Argentina, were classified into three categories (green, brown and clear) according to their optical properties, which are shaped by suspended inorganic solid matter and weed algal biomass. Satellite image processing was used to characterise the temporal variation in the turbidity of the shallow lakes (Dukatz et al., 2005).

In Buenos Aires Province, the number of shallow lakes is on the order of 300000 , including both permanent and non-permanent water bodies (Toresani et al., 1994). Most are natural water bodies in agricultural zones with predominance of grain crops and pastures. During normal years in southern Buenos Aires Province, precipitation varies between 600 and $900 \mathrm{~mm}$. The seasonal pattern shows maximum rainfall in autumn and spring (Scian, 2002b). Spatial variation in shallow lakes in Buenos Aires Province is significantly correlated with seasonal climatic events because of their physical characteristics (Quirós et al., 2002). It is important to detect changes in shallow lake morphometry because of the predominance of agricultural land use in the area.

The hypothesis of this study is that the number and morphometric parameters of shallow lakes in southern Buenos Aires Province change in response to precipitation regime variations. This response varies depending on the geomorphology and location of the shallow lakes. This study aims to establish the relative degrees of influence that climatic, topographic and hydrological features have on the distribution of shallow lakes. Special attention is given to variations in distribution and morphometry (Fig. 1) during two distinct hydrological periods that are defined based on annual precipitation values. The data are also considered as a potential basis for more extensive studies of the shallow lakes covering the whole province, including regions experiencing climatic extremes.

\section{MATERIALS AND METHODS}

The annual precipitation record (INTA, 2005) for the period 1970-2007 was analysed by applying the Standardised Precipitation Index (SPI) to define normal and wet years (McKee et al., 1995). Satellite data, provided by CONAE (Comisión Nacional de Actividades Espaciales), for the studied path and row is first available for 1997. Normal and wet years were defined by considering these data and the magnitude of climatic events. No extremely dry year is included in the images of the analysed period (1998-2007) be- 
Table 1. Qualitative variables included in the cluster analysis. Variables cualitativas incluidas en el análisis de cluster.

\begin{tabular}{lcc}
\hline Qualitative Variable & $\mathbf{0}$ & $\mathbf{1}$ \\
\hline Geomorphology & dunes & Plain \\
Soil permeability & low & medium/high \\
Drain density (Dd) & low & medium/high \\
Coastal Line Development (CLD) & CLD $<=2$ & CLD $>2$ \\
Water residence time* & ephemeral & Permanent \\
Total Maximum Length (TML) & TML $<1.74 \mathrm{~km}^{* *}$ & TML $>1.74 \mathrm{~km}$ \\
Area & A $<0.99 \mathrm{~km}^{2 * * *}$ & A $>0.99 \mathrm{~km}^{2}$ \\
Precipitation & west isohyets $700 \mathrm{~mm}$ & east isohyets $700 \mathrm{~mm}^{\text {ist }}$ \\
TML orientation & heterogeneous & east - west \\
\hline
\end{tabular}

* Water residence time during the 1998-2007 period (Bohn et al. 2009).

** TML mean based Toresani et al. (1994).

*** Mean extension of all shallow lakes of the study area during a normal period.

cause no useful images from such a period were available. Hence, Landsat satellite images of the area for the 1998 and 2002 years (taken in spring, in both cases) were selected for spatial analysis and detecting changes in the morphometry of shallow lakes. The study area was limited to path 226, row 087 and path 226, row 086 (Fig. 1). A Geographic Information System (GIS) was used to process the images.
The procedure for assessing lake distribution and detecting morphometric changes relied on satellite images with atmospheric and radiometric corrections (Song et al., 2001), both of which are essential in a multitemporal study. The geometric registration of the GIS data improved the fidelity of relative spatial and absolute location parameters. Images were classified by the ISODATA (Iterative Self-Organizing Data Analysis

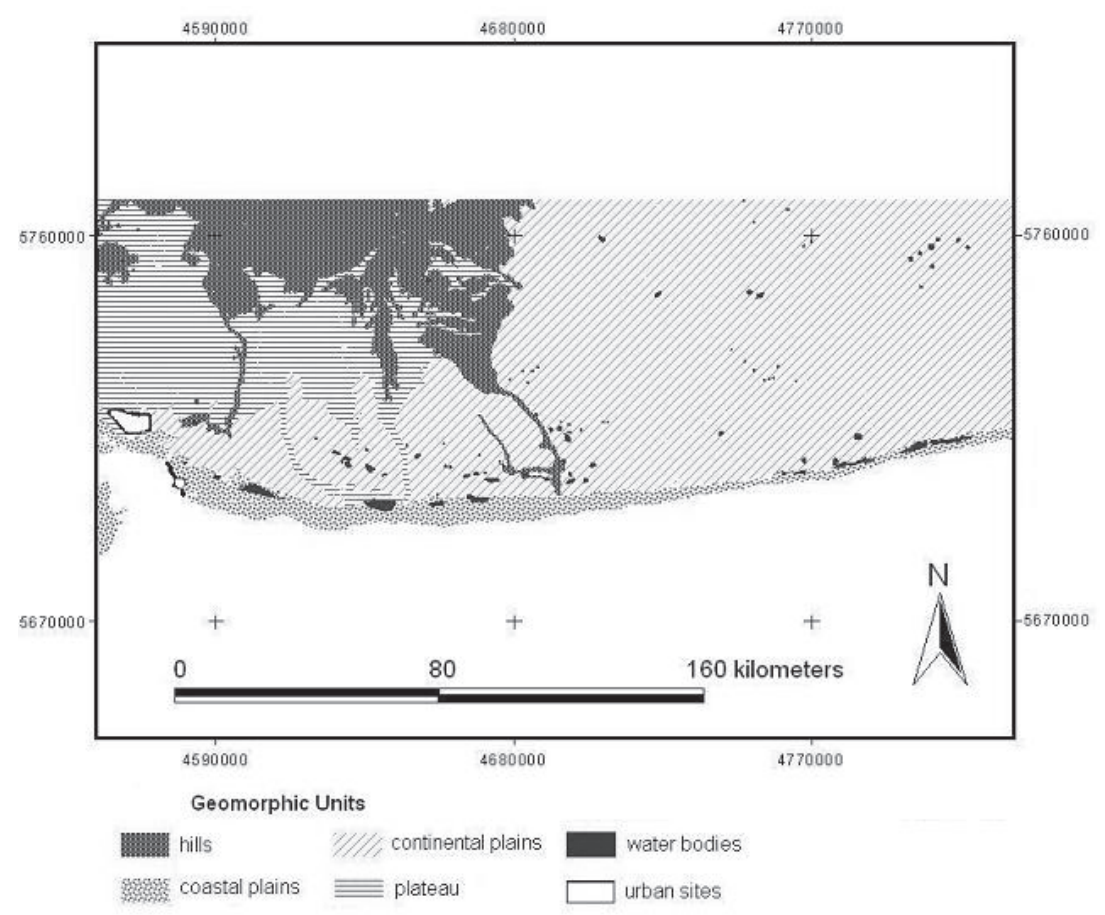

Figure 2. Geomorphological units (INTA 1989) of the study area: hills, plateau, coastal plains, continental plains and depressions. Unidades geomorfológicas (INTA 1989) del área de estudio: sierras, llanura, planicies costeras, planicies continentales y depresiones. 
Technique Algorithm) method. Finally, a class frequency analysis was used to detect changes.

In the first step of the classification process, using the ISODATA method, the unsupervised classification indicated 15 classes. To improve the accuracy of the determination of features, the 15 detailed classes were reduced manually to 2 classes and converted to polygons: water and non-water.

Lakes that share some common traits were grouped into four categories by cluster analysis. The cluster analysis was closely based on the average linkage agglomeration method. The qualitative variable was codified using presence/absence criteria. Variables used in the cluster analysis are shown in Table 1. A multiple correspondence analysis (on the same variables shown in Table 1) complemented the cluster analysis. Variables used in the cluster analysis and multiple correspondence analysis are shown in Table 1. The spatial distribution of shallow lakes was defined using data from a regional geomorphological study, the regional precipitation regime, edaphic characteristics and lake morphometry. The geomorphic units defined by INTA (1989) were used to analyse the distribution of shallow lakes in relation to the geomorphology of the study area. Therefore, five geomorphic units (Fig. 2) were included: hills, plateaus, coastal plains, continental plains and depressions. Hills and plateaus represent $15.96 \%$ and $16.61 \%$ of the study area, respectively. Coastal plains occupy $6.31 \%$ of the area, and continental plains occupy $61.11 \%$. The units described as "depressions" (INTA, 1989) are the least common, occupying $0.94 \%$ of the area. In coastal plains, the distribution of water bodies is influenced by the presence of loess and coastal dunes. Geomorphological features were also evaluated using a Digital Elevation Model (DEM) (USGS, 2004). The relationship established between the spatial distribution of shallow lakes and the regional geomorphology facilitated the drawing of active river channels, palaeochannels (remnants of river and stream channels that have been filled with sediments of active channels) and basins with the Hec Hms Arc View tool. This hydrological modelling tool is designed to be used with the ArcView Geographic Infor- mation System. By analysing digital terrain information, Hec Hms Arc View transforms the drainage paths and watershed boundaries into a hydrological data structure that represents the watershed response to precipitation (US Army Corps of Engineers, 2003). Geomorphological analysis was completed with the palaeochannel analysis and the relationship of palaeochannels to the terrain slope, which was obtained from the DEM data and GIS operations. Edaphic permeability was also incorporated into the GIS database because of its influence on surface and subsurface flows.

To calculate the drainage density (Dd), the basins under study were delimited with the Hec Hms tool and a DEM (USGS, 2004). The drainage density $(D d)$ parameter, a useful measure of topographic texture in fluvial eroded landscapes (Abrahams \& Ponczynski, 1985), was calculated by non-permanent and permanent river length values of the region basins as

$$
D d=\frac{L}{A}
$$

where $L$ is the total channel length $(\mathrm{km})$ and $A$ is the total basin area $\left(\mathrm{km}^{2}\right)$. The river length and other cartographic data were digitised in this study from the 1:50000 topographic sheets (Instituto Geográfico Militar, IGM).

The morphometric features of the shallow lakes were determined according to the systematic description of the Argentine Pampean plains by Dangavs (2005). Coastal Line Development $(C L D)$, Total Maximum Length (TML; the longest axis of a water body), Effective Maximum Length $(E M L)$, Perimeter $(P)$, Area $(A)$, Maximum Wide $(M W)$ and predominant orientation of the $T M L$ were calculated by means of GIS operations and satellite image processing.

The $C L D$ is the ratio of the length of the shoreline perimeter $(P)$ to the circumference of a circle of area $(A)$ equal to that of the lake. The advantage of using the $C L D$ is that it reflects the lake's potential for the development of littoral communities, which usually have high biological productivity. This parameter is given by

$$
C L D=P /\left[2 \cdot(\pi \cdot A)^{1 / 2}\right]
$$


A $C L D$ value of 1 indicates a circular shape (Class I); a $C L D$ value between 1 and 2 indicates a sub-circular lake (Class II); and a $C L D$ value $>2$ indicates an elliptical lake (Class III). $C L D$ is large for lakes in flooded river valleys. The perimeter $(P)$ was measured from Landsat satellite images. Given the spatial resolution $(30 \mathrm{~m})$ of these images, these perimeter values are overestimates. Nevertheless, the values were incorporated into the $C L D$ equation because this parameter was only used for comparison, (between lakes) and the same error affected both datasets. Because of the large number of shallow lakes analysed, the depth $(Z)$ was obtained from databases and previous research (Quirós et al., 2002; Geraldi, 2003; SRH-INA, 2005; Bohn, 2009). As a result, the values for this parameter were only obtained for a limited number of water bodies.

\section{RESULTS}

\section{Determination of wet and normal years based on precipitation}

The years 1998 and 2002 were chosen as "normal" and "wet" periods, respectively. The difference between mean annual precipitation for wet and normal periods was greater than 200 $\mathrm{mm}$. In all cases, the annual precipitation values for 1998 were close to the normal value (Scian, 2002a) for the study area.

During the normal year, the total surface covered by water was $324.17 \mathrm{~km}^{2}(1.11 \%$ of the to- tal studied area), whereas during the wet year, the total surface covered by water was $415.29 \mathrm{~km}^{2}$ ( $1.42 \%$ of the total studied area). The $0.31 \%$ difference represents about $90 \mathrm{~km}^{2}$ of an important agricultural area, a surface larger than any individual water body analysed.

\section{Drainage density (Dd) and precipitation regime}

The hydrological analysis showed that in eastern basins, the hydrological network includes nonpermanent watercourses alternating with small water bodies, resulting in chain-like arrangements. In this area, the regional slope does not exceed $3^{\circ}$ (Fig. 1), and the predominant drainage pattern is dendritic because of the lack of structural controls. As a consequence, a large number of ephemeral shallow lakes and intermittent marshes are generated. There are some shallow lakes with origins in the confluence of two streams, but such lakes are rare.

The geomorphological analysis showed that the Ventania Hill System (VHS) (Fig. 1) has an influence on palaeochannel development. In the eastern and western area, the palaeochannels and superficial courses originate in these hills. Because of the low regional slope in the east, runoff waters in this region slowly flow south. In contrast, in the western zone, most of the streams are permanent and more torrential than in the central area, with a maximum regional slope (calculated from the DEM) of $55^{\circ}$ and a minimum of $4^{\circ}$. A large number of channels end in a neighbouring basin and flow into a shallow lake. In the west and

Table 2. Depth, shoreline development (CLD), area and total maximum length (TML) of some shallow lakes. Profundidad, Desarrollo de Línea de Costa (DLC), área y Longitud Máxima Total (LMT) de algunos lagos someros.

\begin{tabular}{|c|c|c|c|c|c|c|c|c|c|c|c|}
\hline \multirow{2}{*}{ Lake } & \multicolumn{2}{|c|}{ Depth* (Z) (m) } & \multicolumn{2}{|c|}{ CLD } & \multicolumn{3}{|c|}{$\operatorname{Area}\left(\mathbf{k m}^{2}\right)$} & \multicolumn{3}{|c|}{ TML (km) } & \multirow[t]{2}{*}{ References* } \\
\hline & maximum & mean & 1998 & 2002 & 1998 & 2002 & $(\%)$ & 1998 & 2002 & $(\%)$ & \\
\hline La Tigra & 5 & 1.30 & 2.13 & 2.15 & 3.28 & 3.92 & 16.33 & 3.02 & 3.26 & 9.82 & (Bohn 2009) \\
\hline El Cajón & 3 & $\mathrm{n} / \mathrm{d}$ & 5.15 & 3.03 & 11.00 & 11.17 & 1.52 & 6.73 & 7.42 & 9.30 & (Bohn 2009) \\
\hline Calderón & 1.20 & 0.70 & 1.55 & 1.52 & 1.03 & 1.31 & 21.37 & 1.24 & 1.33 & 6.77 & (Bohn 2009) \\
\hline Malaver & 2 & $\mathrm{n} / \mathrm{d}$ & 2.17 & 2.00 & 0.74 & 1.64 & 54.88 & 1.60 & 2.19 & 46.58 & (Geraldi 2003) \\
\hline Sauce Grande & 1.80 & 1.10 & 5.90 & 5.92 & 22.30 & 30.26 & 26.31 & 8.36 & 9.19 & 13.71 & (SRHN 2002) \\
\hline Unamuno & 3 & 0.80 & 10.22 & 7.34 & 9.20 & 16.47 & 44.14 & 6.34 & 10.23 & 38.42 & (Bohn 2009) \\
\hline Aituén & 2 & 0.60 & 2.47 & 2.30 & 0.61 & 0.70 & 12.86 & 1.08 & 1.55 & 30.32 & (Quirós et al. 2002) \\
\hline Tupungato & 2 & 0.60 & 1.80 & 5.14 & 0.92 & 0.90 & 32.22 & 0.76 & 1.30 & 41.54 & (Quirós et al. 2002) \\
\hline
\end{tabular}


Table 3. Area, TML, EML, MW and CLD of some lakes during a normal year. Área, LMT, LME, AM y DLC de algunos lagos durante un año normal.

\begin{tabular}{|c|c|c|c|c|c|}
\hline Lake/Reservoir & Area $\left(\mathbf{k m}^{2}\right)$ & TML (km) & EML (km) & MW (A/LMT) & CLD \\
\hline Calderón & 1.03 & 1.24 & 1.25 & 0.82 & 1.55 \\
\hline El Carrizal & 0.15 & 0.62 & 0.62 & 0.23 & 2.17 \\
\hline El Toro & 2.93 & 2.75 & 2.75 & 1.06 & 1.93 \\
\hline La Tigra & 3.28 & 3.02 & 3.02 & 1.09 & 2.13 \\
\hline Tupungato & 0.92 & 0.76 & 0.76 & 0.66 & 1.80 \\
\hline Paso de las Piedras reservoir & 19.76 & 9.46 & 9.46 & 2.09 & 4.37 \\
\hline San Antonio & 0.41 & 0.89 & 0.89 & 0.46 & 1.46 \\
\hline Malaver & 0.74 & 1.60 & 1.26 & 0.46 & 2.17 \\
\hline Sauce Grande & 22.30 & 8.36 & 9.44 & 2.67 & 5.90 \\
\hline Unamuno & 9.20 & 6.34 & 6.34 & 1.45 & 10.22 \\
\hline El Cajón & 11.00 & 8.07 & 11.13 & 1.36 & 5.15 \\
\hline La Salada & 0.59 & 1.13 & 1.13 & 0.52 & 1.61 \\
\hline $\mathrm{s} / \mathrm{n}\left(38^{\circ} 49.33^{\prime} \mathrm{S} ; 61^{\circ} 30.25^{\prime} \mathrm{W}\right)$ & 3.20 & 2.94 & 3.30 & 1.08 & 2.67 \\
\hline La Blanca & 2.85 & 3.23 & 3.23 & 0.88 & 3.71 \\
\hline De la Yegua & 2.20 & 3.48 & 3.48 & 0.63 & 2.14 \\
\hline
\end{tabular}

in the centre of the study area, the drainage density is lower than $0.01 \mathrm{~km} / \mathrm{km}^{2}$, whereas in the east, it surpasses the $0.1 \mathrm{~km} / \mathrm{km}^{2}$.

\section{Morphometry of shallow lakes}

For all morphometric parameters, the values increased in 2002 in comparison with the values from 1998. In both periods, the highest shallow lake number was found in the central and eastern regions of the area under study.

The Coastal Line Development (CLD) showed the highest variation between periods; the lowest CLD values were a consequence of the formation of small and circular shallow lakes during the wet period. The lakes also showed irregularities when their volume increased after a wet event and CLD values were larger. The mean values of CLD were low during both periods: 1.76 (1998, normal year) and 1.99 (2002, wet year). Circular forms were predominant. The maximum values were 10.22 and 9.11 during the normal and wet years, respectively. The minimum values were $\leq 2$ in both years (Tables 2 and 3 ).

Like other parameters, the $\mathrm{P}$ of the water bodies increased from the normal to the wet year. $P$ values varied because of the influence of the precipitation regime on the shapes of shallow lakes (e.g., during the wet year, a larger water body is developed from two smaller ones by coalescence).

Depth and LMT values of some shallow lakes of the study area illustrate the general patterns of variation. The La Tigra shallow lake (Fig. 3) was the deepest water body studied; the maximum and mean depths were $5 \mathrm{~m}$ and $1.30 \mathrm{~m}$, respectively (Table 2). It is located in the eastern region of the study area. The variations in its area and its TML from 1998 to 2002 were $16.33 \%$ and $9.82 \%$, respectively. The El Cajón shallow lake (Fig. 3) is located in the continental plain and has a $3 \mathrm{~m}$ maximum depth (Table 2). The area and TML of this lake increased $1.52 \%$ and $9.30 \%$, respectively, from the normal to the wet year. Also in this geomorphic unit is the Calderón shallow lake, with a maximum depth of $1.20 \mathrm{~m}$ (Table 2), and the Malaver shallow lake, with a maximum depth of $2 \mathrm{~m}$ (Table 2).

In the coastal dunes region, the representative cases are the Sauce Grande and Unamuno shallow lakes (Fig. 3). Sauce Grande had a maximum depth of $1.80 \mathrm{~m}$ and a mean depth of $1.10 \mathrm{~m}$, whereas Unamuno had an approximate maximum depth of $3 \mathrm{~m}$ (Table 2). The Aituén and Tupungato shallow lakes (Fig. 3), in the eastern region of the study area, have maximum depths of $2 \mathrm{~m}$ and a mean depth of approximately $0.60 \mathrm{~m}$ 


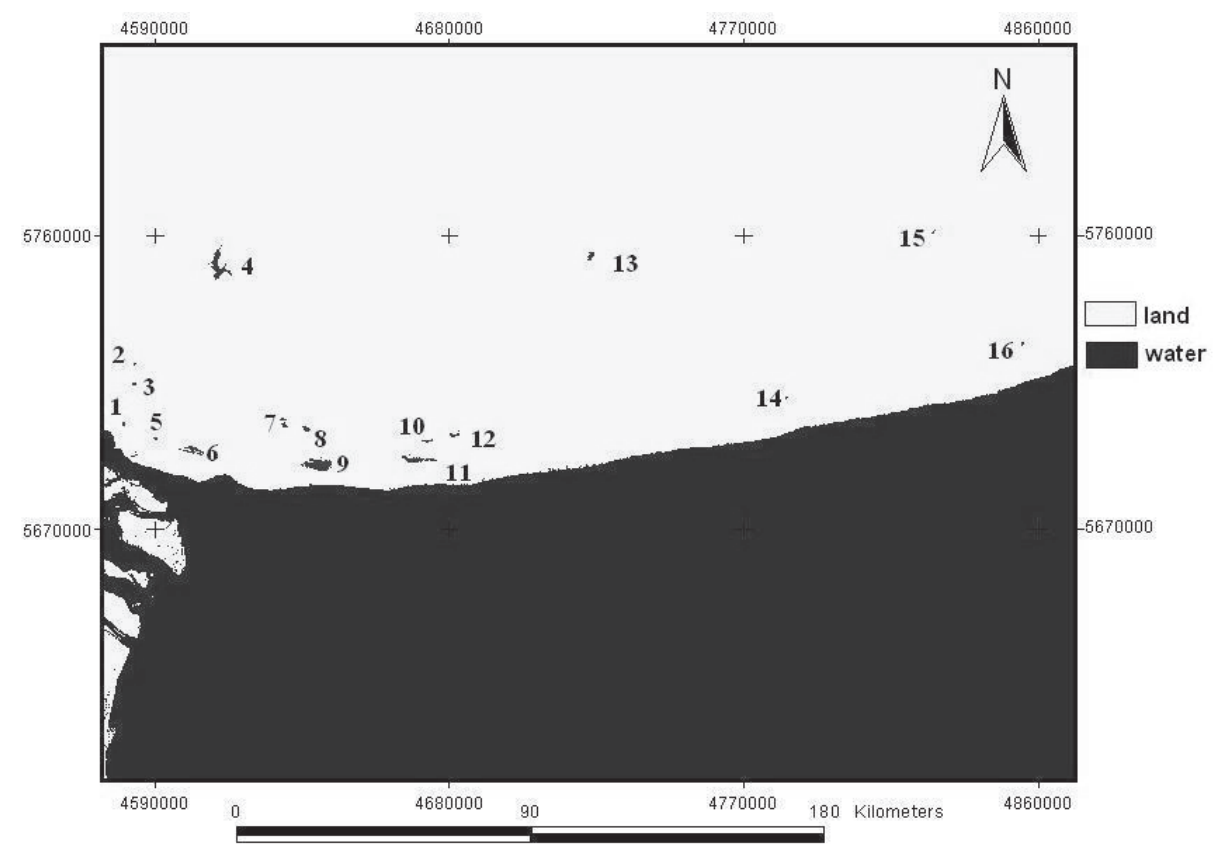

Figure 3. Some shallow lakes of the study area: 1) San Antonio; 2) La Salada; 3) Calderón; 4) Paso de las Piedras Reservoir; 5) Malaver; 6) Unamuno; 7) unnamed; 8) El Toro; 9) Sauce Grande; 10) De la Yegua; 11) El Cajón; 12) La Blanca; 13) La Tigra; 14) El Carrizal; 15) Aituén; 16) Tupungato. Algunos lagos someros del área de estudio: 1) San Antonio; 2) La Salada; 3) Calderón; 4) Paso de las Piedras Reservoir; 5) Malaver; 6) Unamuno; 7) sin nombre ; 8) El Toro; 9) Sauce Grande; 10) De la Yegua; 11) El Cajón; 12) La Blanca; 13) La Tigra; 14) El Carrizal; 15) Aituén; 16) Tupungato.

(Table 2). Because the described shallow lakes are representative of the whole study area, we can assume that the shallow lakes have an average depth of about $1.2 \mathrm{~m}$ and maximum depths between 3 and $5 \mathrm{~m}$. Nevertheless, because of the lakes' morphology, the deeper portions of these lakes have relatively low areas either at the centre (in the case of symmetric, bowl-shaped lakes) or towards one of the borders (in asymmetric lakes).

The Total Maximum Length (TML) was drawn in a straight line in the majority of cases because of the predominance of elliptical and circulars forms in the shallow lakes in the study area. In these cases, the TML was equal to the Effective Maximum Length (EML). The highest TML from 1998 was longer than $9 \mathrm{~km}$ (Sauce Grande shallow lake, Table 2), whereas during the wet year, the highest TML value was $12 \mathrm{~km}$, recorded in the southeast region of the study area. In both years, the TML was less than $0.50 \mathrm{~km}$ in $86.91 \%$ of shallow lakes in 1998 and $84.72 \%$ in 2002. About $12 \%$ of shallow lakes had a TML between 0.5 and $2 \mathrm{~km}$ during the periods analysed. Only 0.67 and $0.71 \%$ of the shallow lakes had TML values greater than $3 \mathrm{~km}$ during the 1998 and 2002 years, respectively.

The location of the shallow lakes and their relationship to the geomorphic units influenced the orientation of the TML. During both periods, the TML orientation was heterogeneous $(\mathrm{N}-\mathrm{S}, \mathrm{N}-\mathrm{W}$, $\mathrm{NE}-\mathrm{SW}$ ) in the eastern area, whereas in the western area, the TML had a predominantly NE-SW orientation. In contrast, the predominant shallow lake TML orientation was NW-SE in the coastal plain, a response to dune morphology (Fig. 2).

Nine categories of water bodies were established with respect to the area parameter (A). One such category included water bodies whose area was greater than $4 \mathrm{~km}^{2}$. In all categories but that comprising the smallest lakes, an increase in the area of water bodies was observed in 2002. The mean area values were 0.15 $( \pm 0.80)$ and $0.16( \pm 0.90) \mathrm{km}^{2}$ during the years 1998 and 2002, respectively. 
The wet event in 2002 increased the number of small water bodies in the study area. In the Argentinean Pampean plains, during a wet period, a shallow lake often forms when two small neighbouring water bodies join; however, the number of shallow lakes in 1998 was greater than 2000, and in 2002, the number of small water bodies exceeded 2400 .

\section{Distribution of water bodies related to climatic criteria, geomorphology and soil}

From the cluster analysis application, four groups of lakes were differentiated:

Plain and plateau lakes (C1). The lakes in the continental plain and plateau geomorphic units are the most numerous lake group. They primarily differ from the lakes belonging to the other groups in the CLD, with a predominance of circular, shallow lakes, and the heterogeneous TML, which tends to be mainly NE-SW and NW-SE.

In 1998, 2170 shallow lakes were included in this group, whereas during 2002, that number increased to $2523(+13.90 \%)$. The mean TML was $1.10( \pm 0.81)$, and the mean area was 0.11 $( \pm 0.31)$ during the normal year. In 2002, the mean TML was $0.97 \mathrm{~km}( \pm 0.75)$, whereas the mean area was $0.59( \pm 0.87)$.

Some aspects of the relationship between climate and hydrology and the relation among water bodies were not considered by this statistical method. From a qualitative perspective, this cluster included lakes belonging to three subzones (Fig. 4): the defined channels zone, the continental plains zone and the eastern basin zone. The essential differences between these classes lie in the number and dynamics of the water bodies. This difference relates the non-existence of a geological control to the highest drainage density in the eastern basins. In the defined channels and continental plain zones, the number of water bodies is low because of the combination of optimal drainage, clay texture and the lowest mean annual precipitation. Some shallow lakes included in this group are the El Toro, La Blanca and $\mathrm{La}$ Tigra shallow lakes (Figs. 3 and 5).

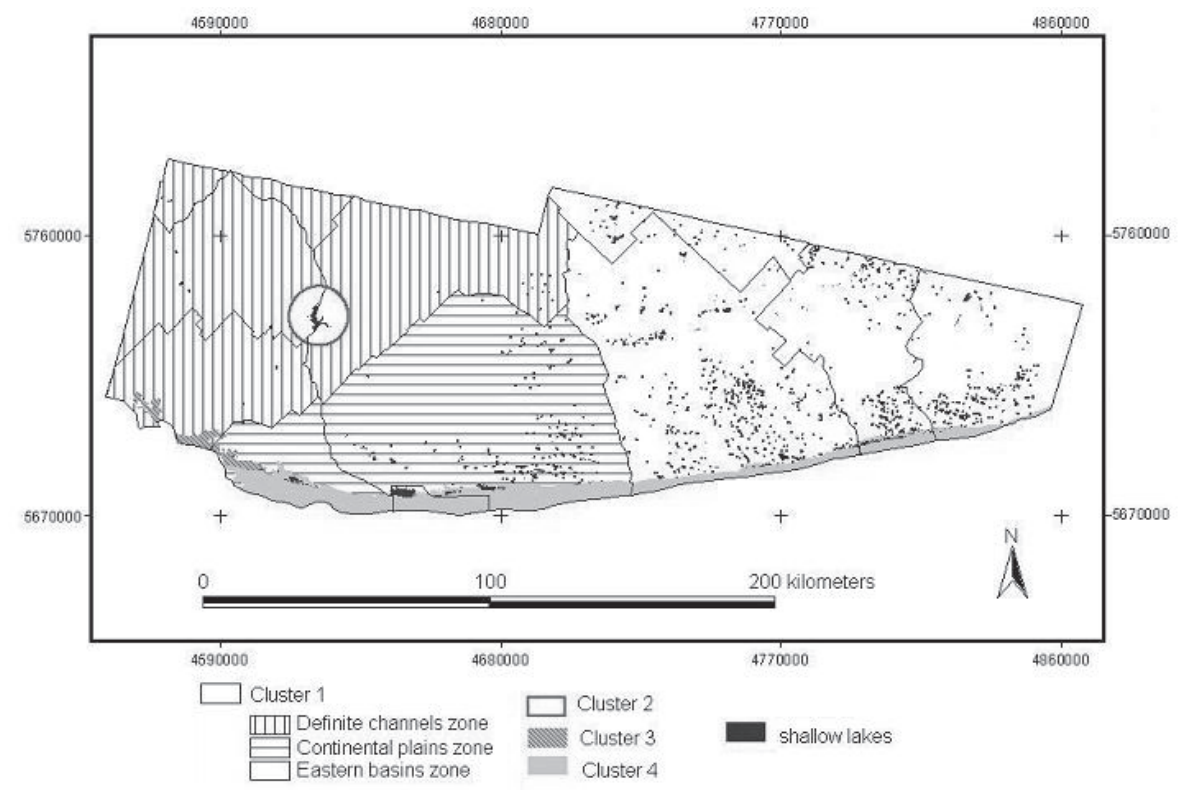

Figure 4. Spatial distribution of water bodies considering hydrological, geomorphological, edaphic and climatic criteria from a cluster analysis. Cluster 1: Lakes of plain and plateau; Cluster 2: Artificial lakes; Cluster 3: Coastal plain lakes (CLD <2); 4: Coastal plain lakes (CLD>2). Distribución espacial de cuerpos de agua en base a criterios hidrológicos, geomorfológicos, edáficos y climáticos (análisis de cluster). Cluster 1: Lagos de planicies y meseta, Cluster 2: Lagos artificiales, Cluster 3: Lagos de planicie costera $(C L D<2)$, 4: Lagos de planicie costera $(C L D>2)$. 
Symmetric graph

( $\mathrm{F} 1$ and $\mathrm{F} 2$ axis: $93.36 \%$ )

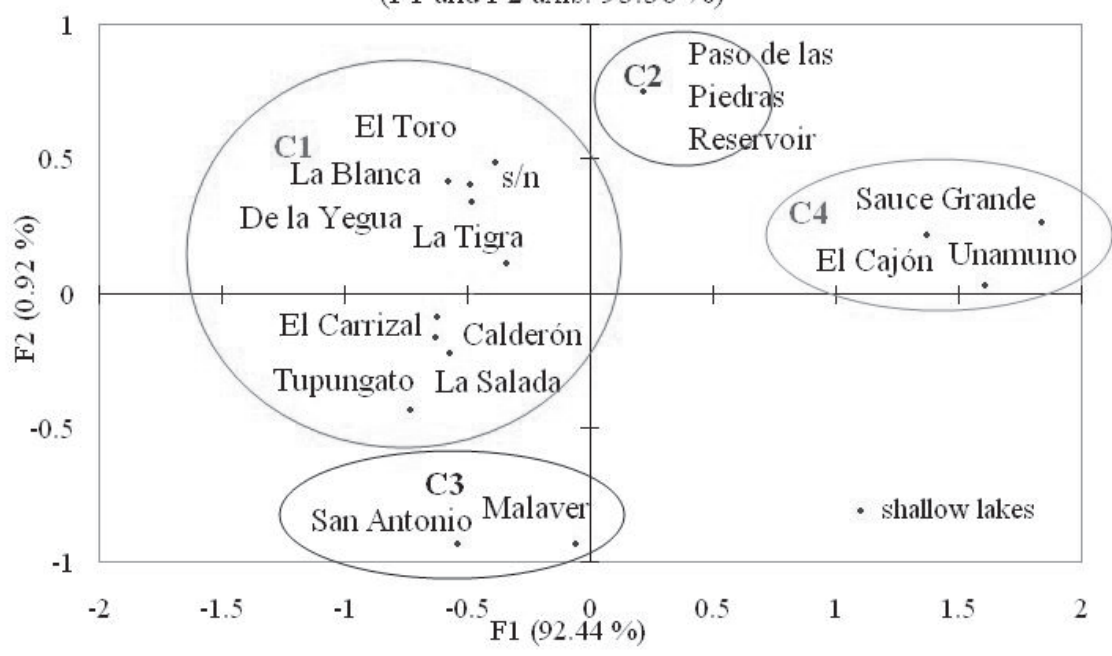

Figure 5. Lake groups by qualitative variables (Multiple Correspondence Analysis, MCA). The contribution of variables was F1 (LMT) and F2 (Area). Grupos de lagos sobre la base de variables cualitativas (Análisis de Correspondencias Múltiples, ACM). La contribución de las variables fue: F1 (LMT) y F2 (Área).

Artificial lakes (C2). This cluster comprised the only artificial water body, Paso de las Piedras Reservoir (Fig. 3 and 5). The reservoir had an extension of about $20 \mathrm{~km}^{2}$ during the normal period, whereas in the wet period, the area increased to $31 \mathrm{~km}^{2}$. The TML increased by $14 \%$ between periods.

Coastal plain lakes, $C L D<2$ (C3). This group includes shallow, circular lakes $(C L D<2)$ located in the southwest region of the area of study. Since a geomorphological point of view, the arrangement of these lakes is related to the dunes along the coast. The TML is the most significant difference between groups 3 and 4 in terms of the orientation of the dunes. The mean TML did not exceed $1 \mathrm{~km}^{2}$ in either period. The mean area for the shallow lakes in this group was $0.57 \mathrm{~km}^{2}( \pm 0.23)$ during the normal year. This parameter decreased during the wet year as a consequence of the development of intermittent shallow lakes, the areas of which did not exceed $1 \mathrm{~km}^{2}$. The number of water bodies increased from 2 to 5 between the studied periods. The San Antonio and Malaver shallow lakes are included in this group (Fig. 3 and 5).

Coastal plain lakes, CLD>2 (C4). This group consists of shallow lakes located in the south- ernmost region of the study area. The CLD of all lakes in this category is larger than 2, indicating that elliptic forms are the most common. The geomorphology of C4 lakes is characterised by the presence of dunes along the coastal zone, which act as the southern border of the lakes. The TML orientation in the water bodies is NW-SE, a response to the presence of those geomorphological features. During the normal period, the mean TML and mean area were $4.72 \mathrm{~km}( \pm 4.14)$ and $6.41 \mathrm{~km}^{2}( \pm 7.19)$, respectively. Both parameters increased by about $25 \%$ in 2002. Sauce Grande, Unamuno and El Cajón shallow lakes are included in this group (Fig. 3 and 5).

During the normal year, the total surface covered by water was greater than $300 \mathrm{~km}^{2}(1.11 \%$ of the total studied area), whereas during the wet year, the total surface covered by water was $415.29 \mathrm{~km}^{2}$ (1.42\% of the total studied area), an increase of approximately $38 \%$. Although the flooded area represents only a small percentage of the total area, flooding is locally important if we consider that an average farm area is around $5.33 \mathrm{~km}^{2}$ in the south of Buenos Aires (SAGPyA, 2002). Our study also demonstrates the importance of considering multiple variables and the usefulness of automated tools, such as those used 
to process satellite imagery, in the classification of natural, regional water bodies.

\section{DISCUSSION}

Variations in morphometry of shallow lakes of the south of Buenos Aires Province, Argentina show a direct correlation with precipitation. Smith et al. (2002) indicated that both the area and density of small water bodies can be explained by simple hydrological considerations. Shallow lakes in temperate and plains zones, as in the study area, exist in a hydrological balance between precipitation and evaporation. In this matter, Harbeck (1962) demonstrated that summer evaporation from small water bodies is most elevated in shallow systems. The abovementioned considerations are relevant for the study area because more than $98 \%$ of the studied water bodies are smaller than $1 \mathrm{~km}^{2}$.

The total area coverage of water increased from the normal to the wet year by about $27 \%$. Similar patterns were detected around the world in the case of floods, droughts or other anomalous events, such as those studied here (Davis \& Froend, 1999; Birkett, 2000; Jöhnk et al., 2004). In some cases, the flood or drought phenomena were complemented by anthropogenic actions, such as urban development, infilling or drainage to create land for agricultural use. Such activities were not detected in the study area.

The morphometric variations in the studied shallow lakes have a significant impact on agricultural activities and local fishing. Because agriculture is the most important economic activity in the Pampean plains, any reduction in workable area, especially in small farms, is potentially crucial. Severe changes in fishing activity are difficult to assess. Dramatic changes in lake water volume have been demonstrated to affect salinity, impact abiotic and biotic conditions, cause a loss of biodiversity and cause the loss or enrichment of nutrients (Kainz \& Lucotte, 2006; Hofman et al., 2008). These variations in morphometry and water level also play important roles in the lake's littoral and aquatic-terrestrial interface processes (Leira \& Cantonati, 2008).
Six groups of lakes were defined in Argentina based on biodiversity, geographical and hydrological characteristics (Reca, 2004). The lakes in the study area belong to a group of water bodies called "The Pampas". In this group, the lakes have a great biodiversity and variability in area. The shallow lakes of flat areas not only present highly variable morphometric parameters, but also include a large number of ephemeral water bodies.

\section{CONCLUSIONS}

The influence of rainfall regime on the morphometry of natural shallow lakes is well recognised at several different scales (Ezzat Elshamy et al., 2006; Swenson \& Wahr, 2009; Turner et al., 2010). We have demonstrated that this influence is quantitatively significant and that geomorphology and hydrology influence this variation.

In the study area, among all parameters analysed, the TML showed the highest variation $(\sim 66 \%)$ in mean values between the normal (1998) and the wet (2002) period. The areal coverage of lakes in the study area was $1.11 \%$ of the total surface of the study area during the normal year. In 2002, this percentage was $1.42 \%$.

As a result of this increased coverage, the density of lakes increased $22 \%$ from the normal to the wet year. Generally, the areal coverage and density of lakes was lowest in the western plateau zones because of the combination of natural optimal drainage with the lowest mean annual precipitation in the study area. Both parameters were low near the hills, moderate in the centre of the study area and high in the eastern plains.

The morphometry of shallow lakes in the study area appears to be correlated with geomorphology, soil permeability and hydrology, rather than structural constraints. Circular, nonpermanent and smaller lakes are correlated with the highest drain density and with plains. Elongated lakes are associated with the presence of coastal dunes, irregular forms, however, were found to be associated with anthropogenic activities, as in the case of the only reservoir in the study area. 


\section{ACKNOWLEDGEMENTS}

Partial support for this study was provided by grants from Comisión de Investigaciones Científicas de la Provincia de Buenos Aires (CIC), Consejo Nacional de Investigaciones Científicas y Técnicas (CONICET), Universidad Nacional del Sur (UNS) and Agencia Nacional de Promoción Científica y Tecnológica (ANPCyT). The satellite data were provided by Comisión Nacional de Actividades Espaciales (CONAE). Special thanks to Dra. Vanessa Negrín.

\section{REFERENCES}

ABRAHAMS, A. D. \& J. J. PONCZYNSKI. 1985. Drainage density in relation to precipitation intensity in the USA. Journal of Hydrology, 75: 383388.

AMBROSETTI, W. \& L. BARBANTI. 2002. Physical limnology of Italian lakes. 1. Relation between morphometry and heat content. Journal of Limnology, 61: 147-157.

BIRKETT, C. M. 2000. Synergistic Remote Sensing of Lake Chad: Variability of Basin Inundation. Remote Sensing of the Environment, 72: 218-236.

BOHN, V. Y. 2009. Hidrografía y geomorfología de las lagunas del sur de la provincia de Buenos Aires. PhD Thesis, Universidad Nacional del Sur. Bahía Blanca. Argentina. 233 pp.

CHERUVELIL, K. S. \& P. A. SORANNO. 2008. Relationships between lake macrophyte cover and lake and landscape features. Aquatic Botany, 88: 219-227.

DANGAVS, N. 2005. Los ambientes acuáticos de la provincia de Buenos Aires. Relatorio del XVI Congreso Geológico Argentino. Geología y Recursos Minerales de la provincia de Buenos Aires, La Plata, Argentina: 219-235.

DAVIS, J. A. \& R. FROEND. 1999. Loss and degradation of wetlands in southwestern Australia: underlying causes, consequences and solutions. Wetlands Ecology and Management, 7: 13-23.

DUKATZ, F., R. FERRATI \& G. CANZIANI. 2005. Clasificación de lagos someros pampeanos mediante imágenes Landsat TM. Biología Acuática, 22: 95-101.

EZZAT ELSHAMY, M., H. S. WHEATER, N. GEDNEY \& C. HUNTINGFORD. 2006. Evaluation of the rainfall component of a weather generator for climate impact studies. Journal of Hydrology, 326:1-24.

GERALDES, A. \& M. BOAVIDA. 2005. Seasonal water level fluctuations: Implications for reservoir limnology and Management. Lakes \& Reservoirs, 10: 59-69.

GERALDI, A. M. 2003. Hidrografía de la Laguna Malaver (Provincia de Buenos Aires, Argentina). Bachelor Degree Thesis, Universidad Nacional del Sur. Bahía Blanca. 45 pp.

HARBECK, G. E. 1962. A practical field technique for measuring reservoir evaporation utilizing masstransfer theory. Geological Survey Professional Paper, 272: 101-105.

HOFMANN, H., A. LORKE \& F. PEETERS. 2008. Temporal and spatial scales of water level fluctuations in lakes and their ecological implications. Hydrobiologia, 613: 85-96.

INSTITUTO NACIONAL DE TECNOLOGÍA AGROPECUARIA (INTA). 1989. Mapa de suelos de la provincia de Buenos Aires. Instituto de Suelos. Buenos Aires. 525 pp.

INSTITUTO NACIONAL DE TECNOLOGÍA AGROPECUARIA (INTA). (2005) Precipitation data 1970-2007. Available from URL: www.inta.gov.ar.

JÖHNK, K. D., D. STRAILE \& W. OSTENDORP. 2004. Water level variability and trends in Lake Constance in the light of the 1999 centennial flood. Limnologica. Ecology and Management of Inland Waters, 34:15-21.

KAINZ, M. \& M. LUCOTTE. 2006. Mercury concentrations in lake sediments. Revisiting the predictive power of catchment morphometry and organic matter composition. Water, Air and Soil Pollution, 170: 173-189.

KOLADA, A., H. SOSZKA, D. CYDZIK \& M. GOLUB. 2005. Abiotic typology of Polish lakes. Limnologica, 35: 145-150.

LEIRA, M. \& M. CANTONATI. 2008. Effects of water-level fluctuations on lakes: an annotated bibliography. Hydrobiologia, 613: 171-184.

MC KEE, T.B., N. J. DOESKEN \& J. KLEIST. 1995. Drougth monitoring with multiple time scales. Ninth Conference on Applied Climatology, American Meterological Society, Dallas, 223-236.

QUIRÓS, R., A. RENELLA, M. BOVERI, J. ROSSO \& A. SOSNOVSKY. 2002. Factores que afectan la estructura y el funcionamiento de las lagunas pampeanas. Ecología Austral, 12: 175-185. 
RECA, A. 2004. Medio Ambiente. In: Geoargentina 2004. Perspectivas del Medio Ambiente. Programa de las Naciones Unidas para el Medio AmbienteOficina Regional para América Latina y el Caribe (PNUMA-ORPALC) \& la Secretaría de Ambiente y Desarrollo Sustentable (SAyDS) de la República Argentina (eds.): 37-216. PNUMA, Buenos Aires, Argentina.

ROONEY, N. \& J. KALFF. 2000. Inter-annual variation in submerged macrophyte community biomass and distribution: the influence of temperature and lake morphometry. Aquatic Botany, 68: 321-335.

SCIAN, B. 2002a. Anomalías hídricas en el centro Sur y Oeste de la Región Pampeana. http//www. criba.edu.ar/sequia/front/index.htm. Valores normales de la región centro, sur y oeste de la región pampeana. Argentina.

SCIAN, B. 2002b. Variabilidad de las condiciones hídricas en la región semiárida pampeana, Argentina. Geoacta, 27: 30-52.

SECRETARÍA DE AGRICULTURA, GANADERÍA, PESCA Y ALIMENTOS (SAGPyA). 2002. Censo Nacional Agropecuario. Resultados definitivos. I Parte. Argentina. www.sagpya.mecon.gov.ar

SMITH, S. V., W. H. RENWICK, J. D. BARTLEY \& R. W. BUDDEMEIER. 2002. Distribution and significance of small, artificial water bodies across the United States landscape. The Science of the Total Environment., 299: 21-36.

SUBSECRETARÍA DE RECURSOS HÍDRICOS (SRH-INA). 2005. Catálogo de Lagos y Embalses de la República Argentina. Secretaría de Obras Públicas MINPLAN. Sistema Nacional de Información Hídrica. www.hidricosargentina.com.ar

SONG, C., C. E. WOODCOCK, K. C. SETO, M. P. LENNEY \& S. A. MACOMBER. 2001. Classification and change detection using Landsat TM data: when and how to correct atmospheric effects?. Remote Sensing of Environment, 75: 230244.

SWENSON, S. \& J. WAHR. 2009. Monitoring the water balance of Lake Victoria, East Africa, from space. Journal of Hydrology, 370: 163-176.

TAVERNINI, S., E. FRATTA, F. SARTORE \& G. ROSSETTI. 2003. Distribution and ecology of calanoid species in relation to morphometric and chemical characteristics of lakes and ponds of the Northern Apennines (Italy). J. Limnol., 62: 28-34.

TORESANI, N. I., H. L. LOPEZ \& S. E. GÓMEZ. 1994. Lagunas de la provincia de Buenos Aires. CARIS-INA. 108 pp.

TURNER, K. W., B. B.WOLFE \& T. W. D. EDWARDS. 2010. Characterizing the role of hydrological processes on lake water balances in the Old Crow Flats, Yukon Territory, Canada, using water isotope tracers. Journal of Hydrology, 386: 103-117

VEGA, J. C., J. J. DE HOYOS, J. ALDASORO, J. DE MIGUEL \& H. FRAILE. 2005. Nuevos datos morfométricos para el Lago de Sanabria. Limnetica, 24: 115-122.

UNITED STATES GEOLOGICAL SURVEY (USGS). 2004. Digital Elevation Model (DEM). Available from URL: http://gisdata.usgs.net. Accesed January 2007.

US ARMY CORPS OF ENGINEERS HYDROLOGIC ENGINEERING CENTER. 2003. Geospatial Hydrologic Modeling Extension Hec-GeoHMS. User's Manual. Version 1.1. California. USA. $281 \mathrm{pp}$.

WANG, Y., J. D. COLBY \& K. A. MULCAHY. 2002. An efficient model for mapping flood extent in a coastal floodplain using Landsat TM and DEM data. Int. J. Remote Sensing, 23: 3681-3696.

WETZEL, R. G. 2001. Limnology. Academic Press. $1006 \mathrm{pp}$. 